\section{Research Article}

(c) 2021 Iskandar et al. This is an open access article licensed under the Creative Commons Attribution-NonCommercial 4.o International License (https://creativecommons.org/licenses/by-nc/4.o/)

\title{
The Relationship Between Intellectual Capital and Performance of Social Enterprises: A Literature Review
}

\author{
Yusuf Iskandar \\ Joeliaty \\ Umi Kaltum \\ Hilmiana \\ Faculty of Economics and Business, \\ Universitas Padjadjaran, Jl. Raya Bandung Sumedang KM.21, \\ Hegarmanah, Jatinangor, Kabupaten Sumedang, \\ Jawa Barat 45363, Indonesia
}

DOI: https://doi.org/10.36941/ajis-2021-0141

\begin{abstract}
There is a need for competition and having a competitive advantage for every enterprise. Moreover, a social enterprise is expected to maintain itself and expand exponentially through innovation and the application of technology. The need to survive implies the need for social innovation within the organizations. When the organization's goal is established, which is the prerequisite for starting a social enterprise, innovation aims to solve the problem. Innovation is a learning outcome that manifests itself into new product features, new products, or production methods. Social innovation is an incremental form of innovation because it emerges from the social needs of a community. The kind of innovation produced is oriented towards the community to provide a solution to their problem. Social enterprises have worked tirelessly to create solutions to the social issues that specific communities are facing. The findings in this research highlight intellectual capital as one of the most fundamental assets in a social enterprise. When discussed in terms of its three branches, intellectual capital's performance of social enterprises is significantly improved.
\end{abstract}

Keywords: Social Entrepreneurship, Performance, Human Capital, Relational Capital, Structural Capital

\section{Introduction}

The study of intellectual capital and social entrepreneurship has experienced heightened attention over the past decade regarding journals, academic studies, and conferences. Social entrepreneurship (SE) refers to organizations that tend to occupy a unique space in the economy where they sit in between for-profit and not-for-profit divisions while upholding the achievement of a social purpose (Abu-Saifan, 2012). The principal objective of social entrepreneurship is the attainment of an unmet social need. The social benefit is the business idea that needs to be exploited by the organization, managed, and realized to raise revenue. While considering the market-based approach, social enterprises comprise the commercial forms of generating economic value as a vehicle to achieving 
the social mission (Saebi, Foss \& Linder, 2019). According to SE's business model, profits and wealth generation reach SE's social end. Statistics by the European Commission indicate that the social economy covers close to $10 \%$ of the businesses in Europe, with over 2 million SE's registered, employing $6 \%$ of the working population in the region (Agoston, 2014). This illustrates how social enterprises are rising and increasing exponentially across Europe and other parts of the world.

Most individuals are drawn to social entrepreneurship because of the social change drive and the potential payoff with a transformational and lasting benefit to society. Social entrepreneurship is about innovation, collaboration, passion, and the people. Most of the programs designed under social entrepreneurship are highly determined and inspired by the people they assist (Zeglat \& Zigan, 2013). The cutting-edge solutions developed are meant to deal with problematic issues in society and improve the people's livelihood in the community. Most pressing societal needs force social innovators to create inventive and sustainable solutions to these issues (Lai, 2013). If a society requires food, a social entrepreneur will learn to grow food and provide the community with crops that will do well in the region instead of a one-off meal. Social entrepreneurs are business savvy and community-conscious, but above all, they are passionate about their job since they face immense challenges that require diverse solutions to improve the enterprise (Rahim \& Mohtar, 2015). The growing number of social entrepreneurs in a rather profitable area has led to the need to explore different ways of conducting business to ensure it is better, efficient, and productive.

Organizations need to change their strategies and policies due to the changing demographics and social development, which have led to increased competition, globalization, a rapidly aging population, and technological advances. Most traditional management strategies are not considered appropriate, hence the need to find the more proper strategy to generate a competitive advantage. Organizations are investing more in customer relations, workforce training, computer systems, research and development, and knowledge sources with such changes. These investments, collectively known as intellectual capital, replace those previously made in financial and physical capital. Most organizations have shifted from traditional and physical capital to intellectual capital because of the competition. Intellectual capital has been ignored for years; it is now a fundamental investment because the economy is currently knowledge-based. Managers, investors, and policymakers are increasingly focusing on intellectual capital (IC) because it influences organizations in significant areas, including economic growth, competitiveness, value creation, business performance, sustainability, and job performance.

\section{Background}

\subsection{Intellectual Capital (IC)}

The modern economy, also called the knowledge economy, has moved the attention of investors and businesses from tangible to intangible investments, which they possess and lend a keen eye on how they are managed. IC is one of the highly prized assets in all companies operating in the new economy. Todericiu and Șerban (2015) have indicated that the reason why intellectual capital is more important than the physical is the analogy that in the $21^{\text {st }}$ century, intangible assets are more valuable than tangible assets (Praszkier \& Nowak, 2011). Additionally, for establishments to stay competitive in the current times, they have to take a methodical tactic to intellectual resources. The definition of intellectual capital has been altered with time; it started as a variance between the value of the market and book value (Cukier et al., 2011). It was later defined as the capacity of an establishment to create value when faced with persistent change. Various scholars, including Torre, Tommasetti, and Maione (2020), thought it was the quantity of all knowledge applied in the procedures of a business that seeks to gain a competitive advantage. The corporate and preferred definition is the possession of goal relationships, professional knowledge, experience, and technological skills applied to give a competitive advantage to an organization.

According to $\mathrm{Xu}$ and $\mathrm{Li}$ (2019), the most fundamental framework of IC comprises three 
constituents: structural capital, human capital, and relational capital. The three components of IC are interrelated and play an essential role in influencing the growth and value position of the business.

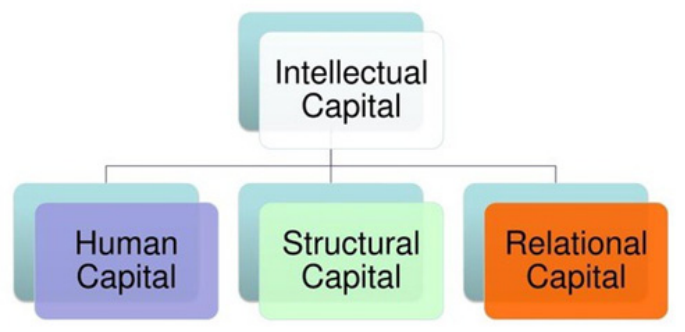

Figure 1: Intellectual Capital

\subsubsection{Human Capital}

According to Yusoff et al. (2019), Human Capital (HC) refers to a measure of education, skills, capacity, and other labor attributes responsible for influencing earning potential and capacity of production. According to the OECD, human capital is the skills, information, and competencies accrued over time by an individual expected to rely on these attributes to produce goods, ideas, or services in market circumstances (Akhavan Rahimi \& Mehralian, 2013). Moreover, human capital is statistically measured in monetary terms as the potential future earnings of the working population. $\mathrm{HC}$ is determined by various factors, including intelligence, emotional intelligence, education levels, geography, judgment, work experience, fame and brand image, personality, habits, and traits. Education is critical in realizing human capital since it forges people's skills and experience in different sectors (Cisneros \& Hernandez-Perlines, 2018). It is imperative to establish that human capital is influenced by improved childhood education and higher education level.

When considering human capital as a constituent of intellectual capital, one considers the contributions made by the employees who utilize their skills, talents, and expertise to perform their respective duties. Furthermore, employees understand that an organization hires them because of their skills and knowledge (Salvi et al., 2020). Organizations understand that to gain a competitive advantage. They must retain innovative and creative employees and create an environment that allows them to pass on their intelligence and skills to other workers within the organization (Phusavat et al., 2011).

\subsubsection{Relational Capital}

Relational capital refers to the association of different workers between suppliers, collaborators, partners, and customers. RC also encompasses trademarks, licenses, and franchises since they have value only when placed in the context of a relationship with customers (Zeglat \& Zigan, 2013). It connects internal resources with external ones, hence manipulating the capability of the society to generate value (Chu et al., 2011). By definition, interpersonal capital is the acquaintance surrounded by interactions with different stakeholders within the organization. A successful organization creates and maintains relational capital.

\subsubsection{Structural Capital}

The skeleton and the adhesive of the organization strengthen it and create a consistent and robust relationship between people and processes. Structural capital is the infrastructure that supports the 
business and empowers the rest of the group to work scalable and repeatable manner (Smriti \& Das, 2017). The organization owns and retains the structure to be followed by different employees when the current leaves. SC encompasses data, processes, knowledge, and designs. It can be used and reused over time without affecting its value since the organization wholly owns it (Dacin, Dacin \& Tracey, 2011). Examples of structural capital include patents, databases, organizational culture, trademarks, and routines. Structural capital is a fundamental dimension that lets structural capital be measured and advanced.

\subsection{Organizational Performance}

Organizational performance has different descriptions depending on how it is measured and the factors considered. It is an imperative subject for for-profit and nonprofit establishments since most organizations seek to improve their performance (Santos, 2012). Different factors affect organizational performance, including environment, strategy, culture, and goals (Dacin, Dacin \& Tracey, 2011). Toth and Jonas (2012) refer to organizational performance as a measure and the ability of organizations to achieve their objectives. Managers should understand that it is not feasible to only depend on the financials to determine the performance level but add other variables (Phillips et al., 2015). The operational performance variables, including quality, cost, flexibility, delivery, and innovation, can be used to measure the organization's internal performance (Sherif \& Elsayed, 2016). These non-financial measures are critical because they are utilized to transfer vision and approach into an instrument that can lead to higher financial gain by influencing performance.

Drawing from this paper's context, the performance of an organization is based on intellectual capital through its three key scopes, namely, human, structural, and relational capital. When the three work unruffled in an interrelated manner, the organization's performance improves significantly (Sardo, Serrasqueiro \& Alves, 2018). It is imperative to establish that managers are tasked with ensuring that intellectual capital is well managed, organized, and steered towards a high-level performance (Pedro, Leitão \& Alves, 2018). The management is responsible for strategic planning, which involves clarifying the organization's goals, purpose, and strategies. All the necessary organizational structures can be aligned to achieve goals and guide the employees towards improving their performance (Cleary \& Quinn, 2016). Some of the enabling factors include socio-economic, economic, and political factors.
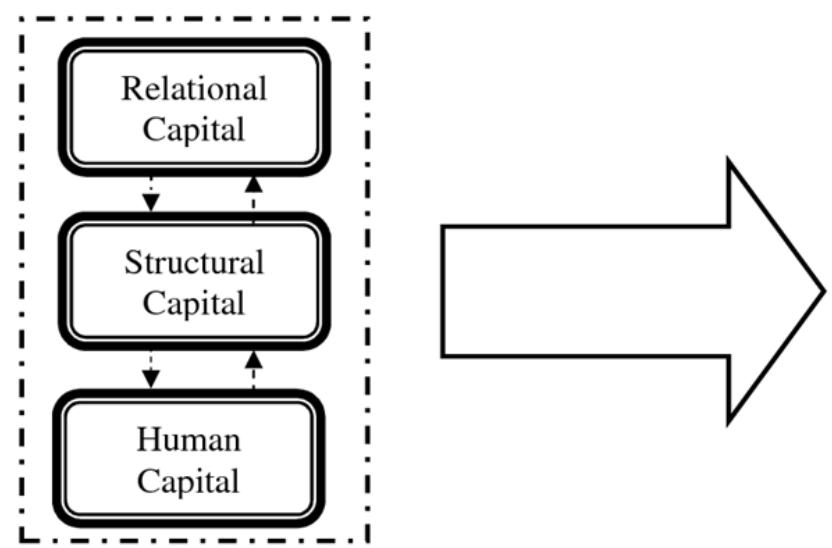

Figure 2: Organizational Performance due to Intellectual Capital

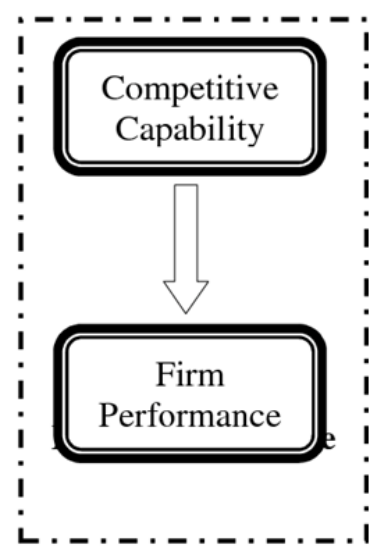




\subsection{Intellectual Capital Development}

With knowledge and reference from multiple sources, intellectual capital is formulated through various management initiatives. To ensure that the organization is achieving its performance goals, the management alters the strategy and maps out the process to ensure it is in line with the mission and vision statements (Hechavarría \& Welter, 2015). The management is expected to hire and make use of human resources. An organization that intends to improve its performance should pay more for highly qualified and skilled personnel. An organization that does not need pushing will effectively achieve the set goals (Örnek \& Ayas, 2015). The management should ensure that the human resource takes part in formulating goals, objectives and making any alterations. It is imperative to establish that the employees take a more active role in the organization when they feel part of the team that takes part in creating the strategic plans.

The organizational leaders should understand the strengths and weaknesses of their teams and their educational background to understand which tasks to assign to them. The organization can choose to provide studies that sharpen the skills of the human resources and make them more tactful and ready for their assignments (Sarwenda, 2020). Organizational efficiency calls for the leadership to be aware of the company's requirements and how the current employees can improve their skills depending on their role (Obeidat, Al-Suradi \& Tarhini, 2016). This falls under the human and relationship capital since the training leads to organizational learning. The company should employ technology to improve efficiency and effectiveness (Chahal \& Bakshi, 2016). It should have a fully operational information technology department to ensure smooth connectivity between employees, faster communications, software installations for different functions.

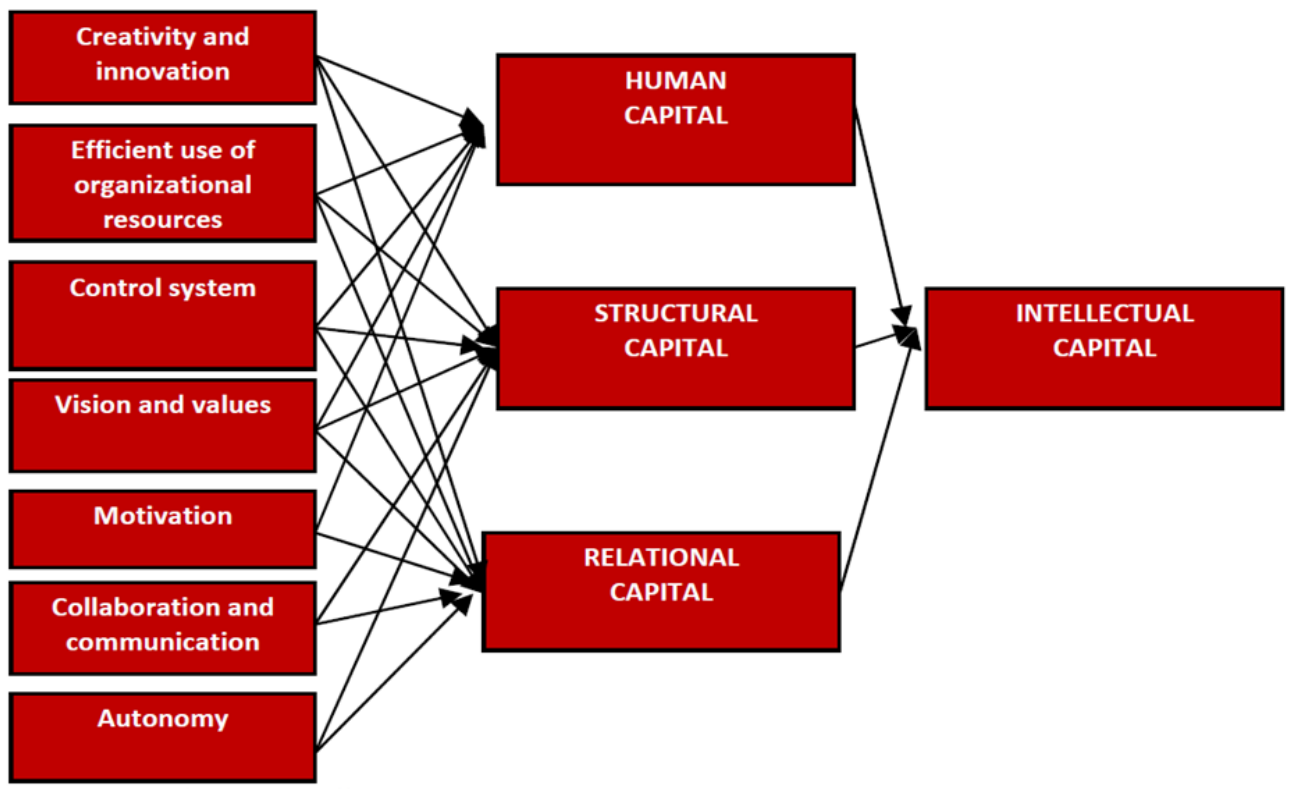

Figure 3: Intellectual Capital Development Process

Intellectual capital can be developed through strategic training and development, focus on the business strategy, and dealing with internal roadblocks (Susanti et al., 2020). The management is called upon to check the system to ensure the policies and work procedures do not affect the company's growth and performance (Hussinki et al., 2017). The strategy of the business should strive 
to develop customer intimacy, leading-edge and operational efficiency. Leading-edge involves the provision of new and innovative products and services (Shehzad et al., 2014). This calls for a robust research function or establishment of a research and development division that is always studying the processes and products to improve them and ensure they efficiently meet the needs of their customers (Scafarto, Ricci \& Scafarto, 2016). Operational efficiency involves providing a universal set of services and products designed to offer the best value to the customer. Most of the development processes and growth programs aim to stream intellectual capital (Huybrechts \& Nicholls, 2012). Organizations are learning more and relying on more technology to achieve efficiency. Companies that spend more on valuable employees and technological systems reap more profits because the businesses are operating on a high-level scale of efficiency with minimum wastage (Noradiva, Parastou \& Azlina, 2016). Intellectual capital as a trade tool considers and emphasizes innovation, customer satisfaction, human resources, and streamlined processes.

\subsection{Knowledge Sharing}

Businesses are operating in a setting described by change, ambiguity, and unpredictability, causing numerous challenges. However, numerous trends have emerged due to globalization, requiring companies to easily and quickly adapt to them to survive (Noradiva, Parastou \& Azlina, 2016). Organizations are investing more in intangible or intellectual capital (El Ebrashi, 2013). This is because knowledge leads to the reinforcement of organizations' central capabilities and provides the essential properties to compete and innovate (Mushref, 2014). Organizations that need to focus on surviving in a competitive and dynamic environment should pay more attention to the concept of knowledge. Organizations need to be competitive. One way of ensuring it is by creating knowledge, sharing it across the organization, and embodying it in modern products and technologies.

The success of an organization depends on how it generates, shares, and manages knowledge. Researchers have previously highlighted the importance of knowledge among organizations. Knowledge is well-defined as the interpretations, intuitions, understanding, wisdom, and context that aid organizations to achieve their mission, vision, goals and help to enhance value (Sharabati, Nour \& Shamari, 2013). Knowledge is divided into explicit knowledge, which denotes the knowledge that can be articulated evidently, while implicit knowledge is difficult to express to people because it is decidedly modified (Mthembu \& Barnard, 2019). Knowledge administration refers to using, taking, and distributing knowledge by using different systems, approaches, and practices.

Organizations are continually developing open cultures which allow personnel to share their understanding and experience with colleagues voluntarily. The flow of tacit information from one individual to another in groups or departments raises an organization's competitiveness. Such businesses train their employees to live harmoniously while allowing their experience to be used by the younger generation (Hamdan, 2018). In some cases, the company plans to sponsor representatives to a training program, hoping to instill the knowledge acquired to the rest of the workers. The process of knowledge sharing involves sharing ideas, suggestions, information, and experiences (Mondal \& Ghosh, 2012). Organizations are increasing the need for sharing information by showing employees the price of knowledge and helping them discover that tacit knowledge is further essential and treasured than explicit knowledge. Sharing information among employees is crucial because it benefits organizations (Hechavarría \& Welter, 2015). These benefits include assisting the organization in building from previous experiences and knowledge of others, learning how to respond to issues quickly, fostering innovation, developing new ideas, building competencies, and understanding customer needs.

\section{Methods}

A systematic literature review was conducted from relevant published literature. The fundamental purposes of the literature review were to create the relationship between intellectual capital and the 
representation of social enterprises. The researcher was keen to gather data about intellectual capital and its three constituents; human capital, structural capital, and relational capital. With a structured literature review, knowledge gaps can be identified and lead to the development of a theory (Asiaei, Jusoh \& Bontis, 2018). Two subjects are in the limelight, intellectual capital, and social enterprises, and they were used as the keywords when finding suitable journals to utilize in this study. The references were selected from various online research databases. The most common databases include Gartner Research, IBISWorld, Global Economic Monitor, Google Scholar, JSTOR, ProQuest Business, Scopus, Gale PowerSearch, FRASER, ERIC, Web of Science, and ScienceDirect. The search terms consisted of social enterprises, human capital, relational capital, structural capital, intellectual capital, knowledge management, knowledge sharing, and knowledge development.

Table 1: The search results from databases

\begin{tabular}{|l|l|c|}
\hline Database & Search Query & $\begin{array}{c}\text { No. of } \\
\text { Results }\end{array}$ \\
\hline ProQuest Business & $\begin{array}{l}\text { Social enterprises, human capital, relational capital, structural capital, and } \\
\text { intellectual capital. }\end{array}$ & 36 \\
\hline Google Scholar & $\begin{array}{l}\text { Structural capital, intellectual capital, knowledge management, knowledge } \\
\text { sharing, and knowledge development. }\end{array}$ & 87 \\
\hline ERIC & $\begin{array}{l}\text { Social enterprises, human capital, relational capital, structural capital, } \\
\text { intellectual capital, }\end{array}$ & 28 \\
\hline Scopus & Knowledge management, knowledge sharing, and knowledge development. & 43 \\
\hline ScienceDirect & relational capital, structural capital, intellectual capital, knowledge management & 51 \\
\hline
\end{tabular}

However, since the search was extensive, more than 200 articles were retrieved basing on the keyword search and PRISMA Protocol. It is imperative to establish that not all references collected from the search would meet the minimum threshold to be included in the study. The articles and journals were filtered to eliminate duplicates, followed by another assessment which involved manually reading the abstract and the title and determining whether the content was suitable for the study. From a total of 245 articles, 107 were filtered because they were duplicated in different databases. The remaining 138 articles were further scrutinized and analyzed through reading the abstract, title, and conclusion leading to the removal of 18 texts. An in-depth study by skimming through the content of the remaining 120 papers lead to the removal of 20 more articles to remain with 100 excellent articles. Among the 18 articles were some that only discussed the keywords in different subjects other than business. Some were agricultural papers and biological papers because some of the databases, such as ERIC, and ScienceDirect are multidisciplinary. The exclusion criterion was necessary to ensure the information garnered from the sources was rich in the proper context and included the most preferred texts only. The selected texts were further analyzed by conducting a descriptive and content analysis to determine value creation factors. Textual data was reduced, and the texts were classified by theme identification and analysis of frequency. A summary of the exclusion criterion is displayed in the PRISMA Protocol flow diagram below. 


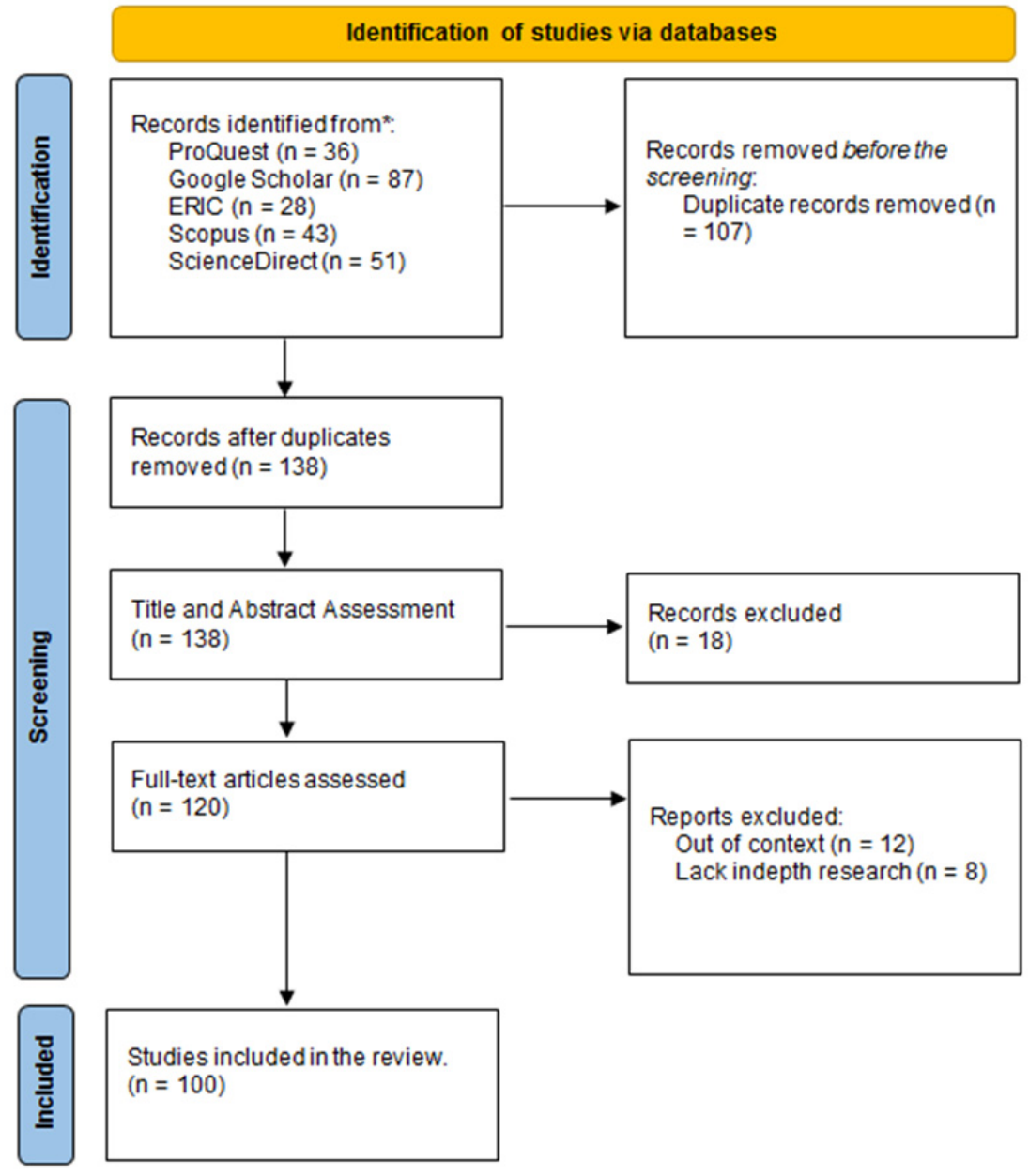

Figure 4: PRISMA Protocol flow diagram

\section{Results}

The papers reviewed applied a wide range of data collection methods and methodological approaches. The papers were instrumental in defining the affiliation between intellectual capital and the growth of social enterprises (Mention \& Bontis, 2013). They contained rich content which provided details about the social enterprises, the rate at which they have grown over the past decade. Intellectual capital is a critical factor in this study; the papers have detailed the concept (Inkinen, 2015). The analysis of the term intellectual entrepreneurship has been explained from its recent history of 2010 to the current 2021 papers. It is imperative to establish that this study was comprehensive and undertaken with caution to ensure that only the most fundamental points are included (Eniola, Entebang \& Sakariyau, 2015). Since 2011, the number of publications in intellectual capital has significantly increased due to the changing economic climate. Most businesses are currently seeking to grow their efficiency and productivity levels by applying and manipulating intangible knowledge (Sgrò et al., 2020). 


\subsection{Content Analysis}

The 100 sources used in this study have provided specific information about the topic of interest and introduced diversified details essential in exploring the subject matter further. Initially, it was challenging to measure intellectual capital because it was a new concept that lacked a theory to back it up (Bleoca, 2016). However, competition kicked in dramatically because of market liberalization, globalization, and new technologies and forced organizations to change their tact and embrace intellectual capital. Most papers have considered intellectual capital an intangible asset to companies (Mehralian et al., 2012). Social entrepreneurship was not common in the past, but it started gaining pace as more business-minded people understood its operations.

Among the sources, various scholars such as Uwuigbe and Uadiale (2011) have described intellectual capital models and how they can be measured. The intellectual capital models are based on market value, asset income, frame scores, and direct evaluation of components of intellectual capital (Jain, Vyas \& Roy, 2017). The technique is designed to evaluate both the strategy and business objectives under the four main perspectives. These perspectives include finance in terms of profitability and income added value, customers focusing on what they desire, internal business processes such as innovation and after-sales services (Franz, Hochgerner \& Howaldt, 2012). The fourth perspective is learning and development encompassing factors such as organizational alignment and employee skills.

\subsubsection{Social Entrepreneurship}

Socially conscious companies include Adobe Systems, Lush, Sanergy, Indiegogo, Good Eggs, Dechen Hawk Music, and the Madison Collection. Social entrepreneurship is becoming common since entrepreneurs have realized that they can build a successful business in pursuit of helping others (Matos \& Vairinhos, 2017). Millennials have diversified their thinking about what a business is expected to do, other than earn profits and positively impact society (Chahal \& Bakshi, 2014). It is imperative to establish that $71 \%$ of millennials believe that their businesses can be profitable while addressing social needs such as climate change, resource scarcity, and income inequality.

The success of a business should be measured by more than its financial gains and how it improves society. Millennials, in general, are aware of the community they live in and wish to make a change in their area of influence, some have signed online petitions that advocate for the needs of the people, others have participated in public giving and charity drives (Shah \& Shah, 2010). Generation Y's perspective of generating profits and, at the same time, helping society has given birth to the rise of social entrepreneurs (Asrar-ul-Haq \& Anwar, 2016). Numerous sources have discussed social entrepreneurship in different aspects, including formation and their performance in the market. A section of the papers has discussed the role of social entrepreneurship in a socially, economically, and politically diverse world.

Social entrepreneurship is shaped and realized with appropriate suppleness where a group of people or a single individual intends to create social value and recognizes and exploits the opportunities arrived at in developing the particular value (Massaro et al., 2019). Social entrepreneurs are characterized by innovation and being extra resourceful. In dispensing social value, most social entrepreneurs rely on technology and innovative practices to handle all risks and deal with any form of scarcity that could arise in the process (Ginesti, Caldarelli \& Zampella, 2018). However, Vratskikh et al. (2016) indicated that social entrepreneurs experience a common problem of lacking early strategic management and research, which could otherwise construct legitimacy. Research around this form of entrepreneurship flows from a community policy aspect to a business aspect (Shannak, Obeidat \& Almajali, 2010). Research around social entrepreneurship measures it in respect to qualitative perspective on issues such as determining whether the idea fits the community's objectives, the nature of innovation, and the quantifiable size of donation and total contribution (Shou, Prester \& Li, 2018). Non-profit establishments have conventionally been alarmed with the community, plummeting the social ills, providing social goods, and supplementing government 
activities to the locals (Masa'deh, Obeidat \& Tarhini, 2016). This perspective is what social entrepreneurs have taken but, in the process, ensuring the endeavors are profitable.

As a considerable number of individuals chase financial freedom through different means, a growing minority of social entrepreneurs is focused on solving fundamental problems the world is facing (The \& Sun, 2012). Through advanced innovations and the latest technologies, social entrepreneurs are geared towards creating an impact that will improve the environment and lives of people. This set of individuals is not contented with making money alone but also adding meaningful value to the world and eliminating social ills.

\subsubsection{Social Enterprises}

Over the past few years, social enterprises have become increasingly popular due to international development programs. It refers to a business that reinvests most of its revenue back into the community to achieve its mission (Martin \& Osberg, 2015). During conceptualization, these companies are meant to produce goods and services and trade like any other business. However, the difference with the other for-profit organizations is found in the social aims, including training, job creation, and provision of local services (Groot \& Dankbaar, 2014). The business is answerable to the broader community for its environmental, social, and economic impact. Most of these organizations are socially owned by a large group of stakeholders or trustees. Depending on the business structures, profits are shared equally among the trustees or set off to benefit the larger community. The United Kingdom (UK) has developed a unique authorized form called Community Interest Company (CIC) intended for those wishing to engage in social entrepreneurship (Alzuod, Isa \& Ismail, 2017). Once an organization is registered under CIC, it cannot generate funds for a particular individual but the entire community. There are different types of social businesses; they include the following;

\subsubsection{Community-Based Social Enterprises}

These businesses focus on the community needs of their immediate people. They operate under a strict structure which ensures there are no loopholes to avert from the primary mission of the enterprise (Joshi et al., 2013). The primary business objective is self-empowerment and refining the excellence of life of the public.

\subsubsection{Hybrid Social Enterprises}

The hybrid social business is inclined towards sustainability and development. However, the fund source for supporting this business is varied and balanced, beginning from social to semi-commercial to full commercial (Benevene et al., 2018). The targeted recipients in this business are teens aged 10-24 years and women. The consumer who purchases this product is either a donor, contributor, or grantor.

\subsubsection{Non-profit-Social Enterprises}

This type of social business is initiated under motivation to mitigate a problem in the community. The demand is for the organization to transform the community through professional management and a competent workforce (Kalkan, Bozkurt \& Arman, 2014). One of the key examples is Generation Indonesia, aimed at making the Indonesian environment better. It manufactures and sells ecofriendly bags to keep the environment clean and install proper waste management systems. 


\subsubsection{Success Factors of Social Enterprises}

\subsubsection{Strong Leadership}

The business can only grow to the extent that the leader wants, the sacrifices they make, their influence, and the resources they invest in the establishment. A strong leader continually replenishes their knowledge and experience to ensure they become more valuable to the business. In return, the business increases in value with new management models, new production lines, and a new mindset (Bin Ahmad \& Mushraf, 2011). Strong leadership will ensure the vision and mission of the company are guiding its daily activities. He or she simplifies them for every employee to facilitate knowledge growth and ultimate accomplishments in the line of business (Noradiva, Parastou \& Azlina, 2016). With a strategic focus entrenched by the leadership, the brand, goals of the company, and actions are all geared towards a targeted objective. For the social enterprise to achieve its ultimate goal, it is imperative to establish that the leader is expected to define their realistic mission and values (Hajir et al., 2015). A leader in the social enterprise ensures the business objective is the ultimate goal, and every project is geared towards the same.

\subsubsection{Human Resources}

The employees are instrumental in achieving the success of social enterprises. Leaders need to ensure they have the most talented people because their efforts will lead to the organization's growth (Kamukama, 2013). The staff should comprise passionate, dependable, and highly qualified personnel who understand and interpret the mission and vision of the organization. HR should focus on hiring employees who have a social entrepreneurial mindset because they will quickly attune their efforts to realize the set objectives (Manna-Rea, 2020).

\subsubsection{Operations}

Operations refer to the daily and long-term functioning of an organization. The operations of a social establishment depend on the products or a service it deals with in the community and what it seeks to achieve (Bontis et al., 2018). The procedures should be evaluated continually to ensure effectiveness and all operations documented and trackable over time. Social enterprises should bear a system that is entirely produced and embeds all the elements of efficiency and effectiveness.

\subsubsection{Marketing}

This involves creating an edge in the market by testing and measuring the results consistently. It is imperative to establish that not every strategy that people try will work for them, hence finding the most appropriate strategy. The fundamental marketing principles in business should be applied consistently to improve the outcome until tested and proven. Marketing attracts new customers by supporting the business's growth and media communication (Chahal \& Bakshi, 2014). A social enterprise is likely to fail if it lacks a proper marketing strategy to ensure its products are distributed and purchased. Strategic media communication and advertisements facilitate an expansion of the customer base.

\subsubsection{Financial Factor}

An organization's finances refer to the entirety of its assets, including things such as properties, sums of money, and materials. On top of maintaining the organization's financial data, this factor also encompasses the product's financial characteristics (Anwar, Khan \& Khan, 2018). Pricing is highly impactful on the customers' perception of the product and how it sells. The management has a role in 
ensuring the products are appropriately priced for profits and attract and maintain consumers. The financial management team should track the finances and provide a report regularly.

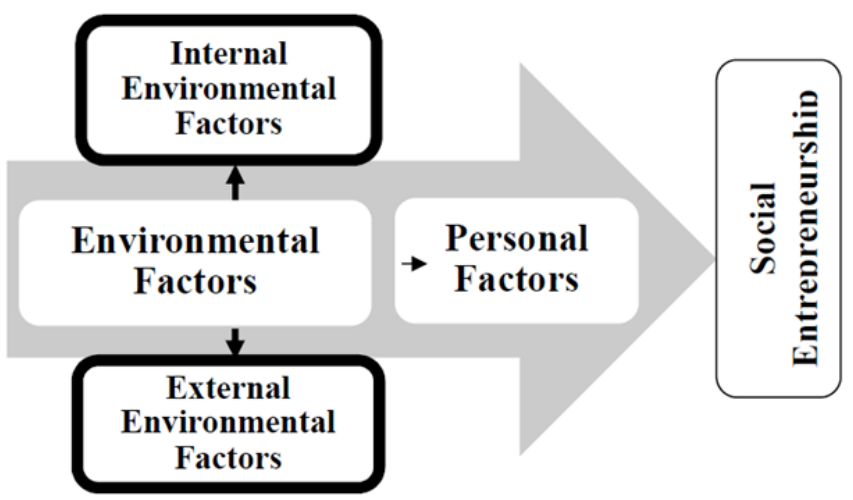

Figure 5: Social Entrepreneurship

The key determinants of social entrepreneurship are concentrated on two fundamental factors, environmental and personal. The environmental factors are classified as internal and external influences. The internal aspects include uncertainty and risk, organization efficiency, availability of funding and resources (Baima et al., 2020). The external environmental factors include social warfare and value, nonprofit organizations, social enterprises, community entrepreneurship, social change agents, social ventures, and new opportunities and innovations. Personal factors lead individuals towards the social business and motivate them to contribute to society (Kamukama, Ahiauzu \& Ntayi, 2010). They include entrepreneurial ability, human character, enthusiasm and willingness, social innovation capabilities, knowledge, education, and skills and experiences.

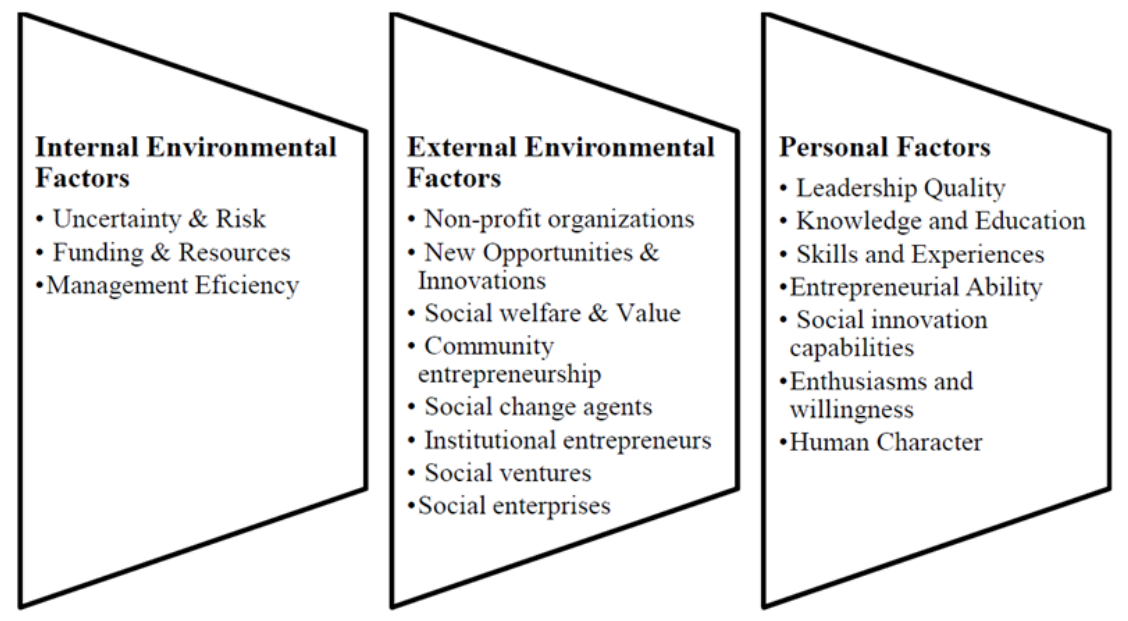

Figure 6: Factors Affecting Social Enterprises 


\subsection{Intellectual Capital Builds Performance}

The success factors highlighted above can only be achieved if the social enterprise incorporates intellectual capital. The research has revealed that intellectual capital is the backbone of achievement for most organizations in the current age. Social entrepreneurs are increasing significantly over time but what stands out is their rate of success which is high (Bayraktaroglu, Calisir \& Baskak, 2019). It is imperative to establish that intellectual assets are responsible for innovativeness, a key ingredient in the formation and achievement of social enterprises. Most researchers emphasize that overcoming the limits of capitalism and other businesses is imperative to reinforce openness and innovation (Madyan \& Fikir, 2019). Open innovation is an instrumental practice incorporating external partners in the creation of value. Different parties head a social enterprise as trustees, shareholders, or investors, but the products are sold to benefit the immediate community (Carraher, Welsh \& Svilokos, 2016). One of the strategies of empowering the community for long-term gain is training them to acquire a skill-set necessary for producing the same goods. Allowing open innovation comes with its advantages since it improves the skills of the community members and widens their knowledge. A well-informed and trained community will help in the production of the goods (Kamukama, Ahiauzu \& Ntayi, 2011). Performance improves significantly when the company's community is trained and possesses the primary skills necessary for production.

Social entrepreneurs are the most innovative entrepreneurs because they are forced to overcome their scarcity of raw materials and expertise. This explains why open innovation is one of the essential aspects that build the presentation of social initiatives. Social magnates trail social assignments that are highly problematic to accomplish (Chahal \& Bakshi, 2014). These entrepreneurs seek to satisfy the unmet social needs but are always met with the scarcity of resources, funding, and human resource. Social entrepreneurs create social and economic values in their environs and represent social establishments as establishments founded to solve social challenges. Open innovation is paramount since social entrepreneurs are expected to cooperate with stakeholders, clientele, the public, and local administration (Maditinos et al., 2011). A high degree of honesty is crucial in innovation because when the different teams meet, they can comfortably discuss how to decipher the varying environmental difficulties and cope with the limited resources available. Social enterprises are successful only when they strive to move towards innovations and success.

The performance of social enterprises is measured two-fold regarding the success of the business profitability and social and community outreach. The economic perspective of performance is determined by investigating the business's financial records (Kateb et al., 2014). When conducting a thorough study, one realizes that a social enterprise requires natural products, which are part of the analysis to understand whether the business is sustainable or not. In most cases, if the raw materials required and the profits made are not in tandem, the business will eventually close down since it is not sustainable (Ariff Islam \& van Zijl, 2016). When conducting a performance study, one looks into all fronts to ensure the organization works with the community to realize the social agenda. Since social performance is linked with economic performance, a social organization will not survive if one is not achieved (Liu, 2017). For instance, an organization that is sufficiently achieving the social purpose but failing to attain the financial aspect will fail eventually. 


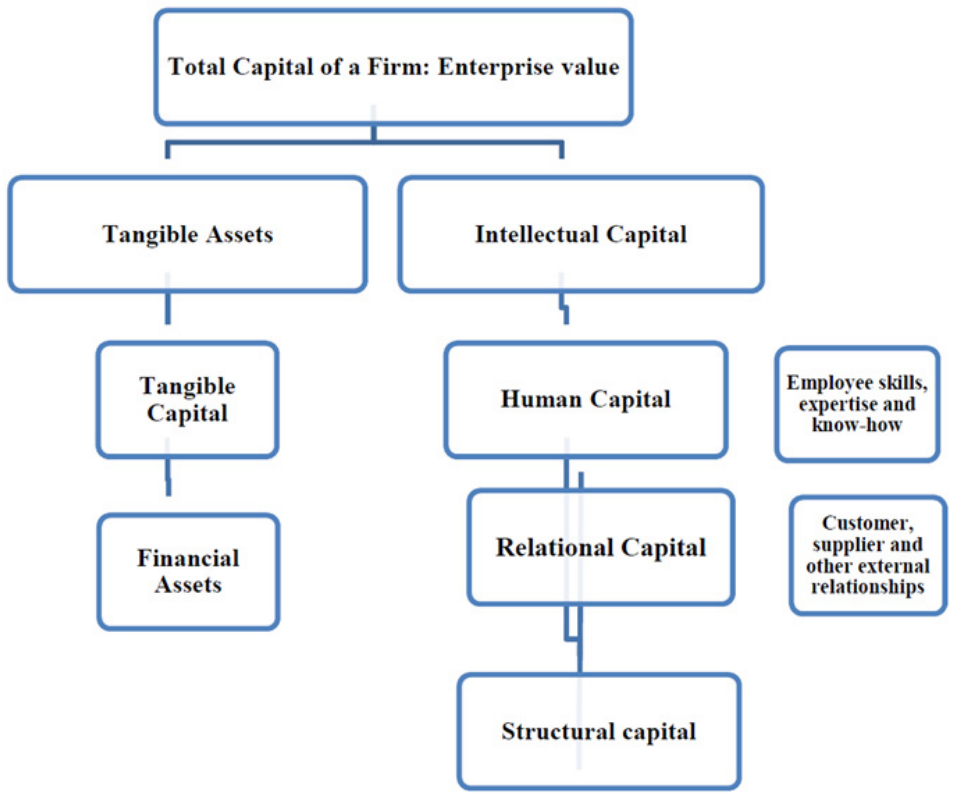

Figure 7: Intellectual Capital Structure

From the intellectual capital structure above, it is imperative to establish that the intangible capital outweighs the tangible capital. Every business can quickly secure funds and build assets, but they could easily fail, especially in the current age, due to a lack of adequately audited intellectual capital (Benevene et al., 2017). Currently, social enterprises are more inclined to intangible capital because of their success rate. Social enterprise performance is measured by how well it accomplishes its social need for organizations that depend on their profits to perform their social duties (Komnenic \& Pokrajčić, 2012). Social entrepreneurs obtain, maintain, and increase their competitive edge by using a resource they own (Käpylä, Kujansivu \& Lönnqvist, 2012). The competitiveness of a social establishment depends on its resources and how it can distinguish between the most fundamental program for a specific community. Social establishments with solid intangible assets generate a lasting competitive advantage.

Both the tangible and the intangible assets are instrumental in securing a competitive advantage for an organization. However, in the $2 \mathbf{2 1}^{\text {st }}$ century, social organizations have heavily invested in intangible assets, especially knowledge acquisition (Lepoutre et al., 2013). In the $21^{\text {st }}$ century, the business models have experienced a paradigm shift where physical assets are no longer responsible for competitive advantage but intellectual capital (Karchegani, Sofian \& Amin, 2013). The $21^{\text {st }}$ century has created a knowledge-based society, making knowledge the only means to competitive advantage.

The knowledge possessed by an organization represents a key influence in the ability to achieve and maintain a higher level of performance. A social enterprise gets its knowledge from the employees and their interactions during and out of work. Organizations that support the free flow of knowledge within them achieve higher results in profitability and production (Komnenic \& Pokrajčić, 2012). Knowledge is attained through studying and experience, and it can be shared among different parties. Wendling, Oliveira, and Macada (2013) have indicated that social organizations established their internal environment have made tacit knowledge systematic. Structural capital makes tacit knowledge systematic and allows it to be used, applied, and diffused within the organization.

The fundamental intangible assets such as high-performance business practices, know-how, and new 
business models can be transferred rapidly worldwide. This destabilized the old model system, which focused on the value delivery model and ushered in the corporate value system. In the past, chains had a limited timeframe within the market, but they are currently disappearing much faster (Lai, 2013). That sired the innovation machine to help organizations stay one step ahead of their competition. The main preoccupation of corporate strategy today is a continuous evolution of capacity and capability. The mature market of the modern economy is advancing rapidly hence the need to stay in business by earning a corporate advantage (Kong, 2010). In the new market, sustainable value creation is no longer experienced or achieved in the economies of scale but exploitation of innovation, scope effects, and arbitrage. Social enterprises are no longer driven by mass production but efficiency and quality of the products (Kuo, 2011). The market is currently determined by the customers and not the price or the brand.

Customers are increasingly interested in the eminence of the merchandise and the producer and their methods of production. Social companies are making more sales on items because customers know that part of the profits is going towards community projects and not enriching an individual (Zeglat \& Zigan, 2013). Upon realizing the shift in the market, most organizations, including the for-profit companies, have started marketing their sustainable goals and measures they are taking in their production lines to be more efficient and use less natural raw materials (Inkinen, 2015). The sustainability aspect of the business is a crucial selling point in the market today. Entrepreneurs gain a competitive advantage because their intentions are known in the community and their methods (Wendling, Oliveira \& Macada, 2013). Social entrepreneurs are investing in technology and innovation, and human capital because it positively influences structural capital.

The creation and maintenance of human capital are crucial in all entrepreneurship because it helps organizations develop innovations and new ideas through better-skilled staff, more absorbed, and have advanced morale. When new ideas and innovations are realized, the company has new knowledge and input into the organizational memory, which generates value generation (The \& Sun, 2012). An organization investing heavily into its human capital gains competent people who develop and improve the structural capital. The existing human and structural capital develop relational capital to produce and deliver products to high-value customers (Toth \& Jonas, 2012). This creates a virtuous cycle in an upward spiral that improves organizational growth and value. For such an organization to retain the high standards of value and production, it is imperative to guard the specificity of the knowledge possessed (Mention \& Bontis, 2013). When an organization intends to create product value and economic growth in a knowledge-based economy, it must uphold knowledge innovation.

Whelan and Carcary (2011) indicate that high-quality employees are the essential factor in business in the present economy. Managers and proprietors train their employees to become more knowledgeable and improve their quality and, ultimately, organizational learning capability. Xu and Wang (2018) believe that training and retaining employees makes it fundamentally credible to earn a competitive advantage within the knowledge economy context. Experienced, long-serving, and tested employees provide wisdom in the organization for present and future corporate success. However, in the present times, the youthful, open-minded, and cavalier business brains are more ready for the technology and knowledge which can change the business value and growth (Khalique et al., 2018). The young group lacks traditional skills, but they are creative and optimistic and can generate new systems, knowledge, and processes.

Knowledge plays a crucial role in supporting competitive advantage across social enterprises, while possessing unique knowledge sets determines how the enterprise will help society (Mushref, 2014). A social organization that starts with a solid team knowledgeable in specific business areas achieves exponential growth. With an enabling environment, it is imperative to indicate that knowledge is shared through interactions, and in the end, new organizational knowledge is achieved. The knowledge is then codified into rules, routines, activity procedures to become structural capital. This knowledge is a representation of the growth and ability of the organization. 


\section{Creating Knowledge-Based Social Enterprises}

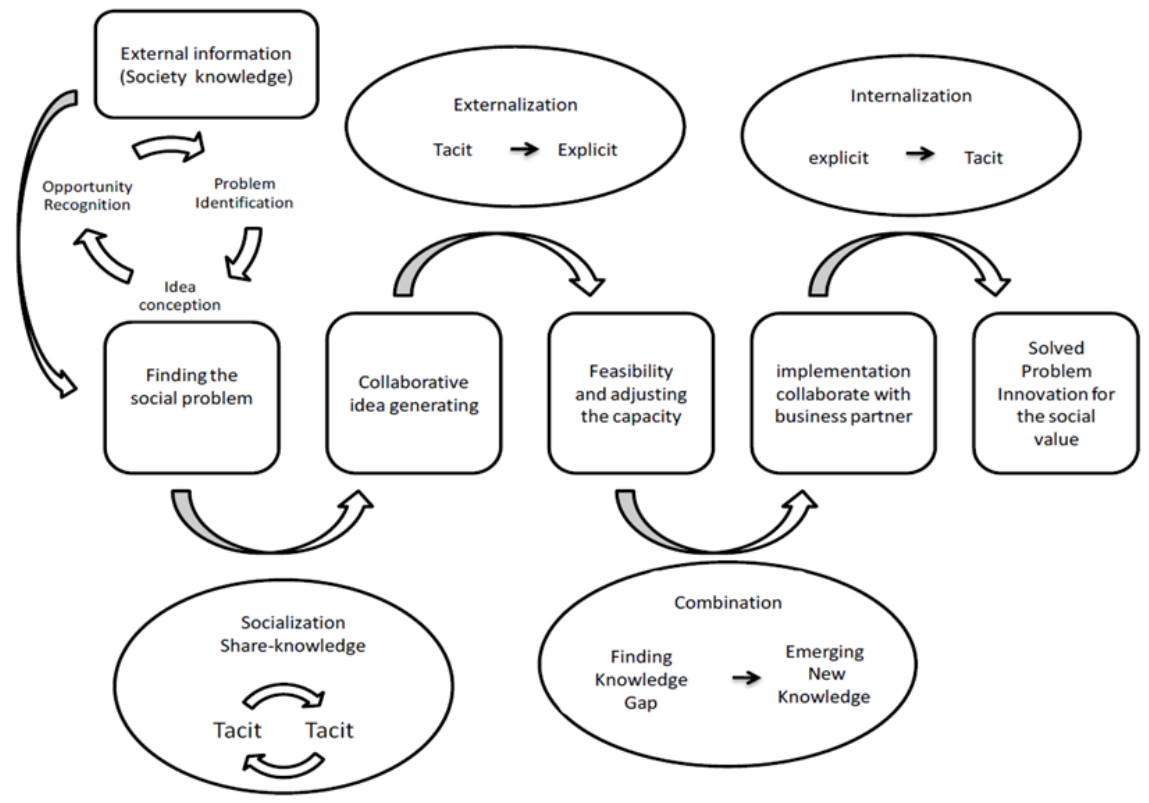

Figure 8: Creating Knowledge-Based Social Enterprises

This study has provided crucial details about social enterprises in the age of knowledge-based economy and explained how this knowledge is used to steer excellence in these organizations. However, this section seeks to provide details on creating or improving a social enterprise through a knowledge-based innovation process (Kim et al., 2012). Every stage of the process illustrated above has its details and a well-constructed description deduced from the study.

The first stage for every entrepreneur is identifying a niche that will be a social challenge and explaining it. The social problem is the foundation needed to conceptualize an idea of a solution (Sherif \& Elsayed, 2016). While identifying a gap between the society's needs and lack of solutions for the same, the external knowledge combines with organizational knowledge of the society leading to the realization of opportunities in the gap identified (Todericiu \& Șerban, 2015). Society knowledge or external knowledge is possessed by an entrepreneur who is in search of problems due to their urge to solve them. Once the social problem has been identified, the entrepreneur starts to generate ideas. At this point, the individual interacts with society to learn more about their problem and to have discussions and conversations (Baima et al., 2020). This is known as tacit-to-tacit knowledge because it focuses on discussions and nothing further. This process leads to an in-depth discussion that provides equality of perception or conformity over the emerging problems towards mutually agreed solutions.

Once the idea has been generated collaboratively, the social enterprise attempts to find the grey area between existing and required knowledge. This stage involves the creation of new knowledge from lessons learned, best practices, and experiences. This knowledge flow is tacit to explicit with the entrepreneur seeking to map out their capacities and does a feasibility study of the potential programs (Kuo, 2011). What follows is analysis for adjustments and determining business feasibility. This stage involves knowledge conversion, in which an internalization is conducted by processing the available explicit knowledge into tacit. The innovation process within a social enterprise involves 
accumulating and processing new knowledge (Abdullah \& Sofian, 2012). The newly processed knowledge forms the grounds for future idea conceptions for potential programs in formulating social values that impact society. This concludes that a social enterprise is formed as a result of interrelated activities for covering a transformation from ideas to inventions for the sake of the community. In the process, new knowledge is created and taken to become part of the organizational knowledge (Sardo, Serrasqueiro \& Alves, 2018). A solved problem is a business for the entrepreneur because the programs started would directly or indirectly help the community.

John Dengler is a classic example of a social entrepreneur who saw a gap in Tampa, Florida, a city that suffers the second-highest homelessness rate after Los Angeles, as indicated by Manna-Rea (2020). Dengler noticed that when people in Tampa do not have monetary value, they lack value altogether, appearing as a burden to the community. Some would find meaningful part-time employment in the city, but the means of traveling across 2,500 square miles of a city was challenging (Manna-Rea, 2020). While driving across the streets, Dengler noticed numerous abandoned bikes chained to city buses, in police custody, around condos, colleges, and apartment blocks. This is a classic example of a wasteful society since the bikes were in their hundreds of thousands.

Dengler saw a society that did not value homeless people or old bikes, and he decided to collect them and refurbish them. While referring to the innovation chart, Dengler first realized a problem in Tampa, Florida, and was willing to do something about it. While moving about in the city, he recognized an opportunity after realizing hundreds of thousands of abandoned bicycles (Manna-Rea, 2020). His idea was to make the bicycles and themselves at half the retail price such that even the cheapest bike in the retail shops was more expensive their Dengler's most expensive bike. While trying to put the homeless together, he found himself at loggerheads with authorities since the law prohibited homeless people from congregating.

He initiated the Earn-a-Bike program, which would see the homeless individuals put in free 10 hours of their labor into repairing the bikes to earning one. The program did not force the homeless to work for free, but it gave them a purpose and belonging. Dengler indicated that having the homeless built their bikes gave their lives a sense of meaning, and he challenged them to use their newly found means of transport to earn a source of income. With reliable means of transport, it was easy to access job opportunities across the city since the long-distance no longer constrained them. The Well Built bike shop belonging to Dengler was a force in the market since it flooded the market with cheap bikes. At the same time, Dengler was earning from the bikes since he would sell them to the locals of Tampa. The Well Built Bike shop is an example of a social initiative that is changing the lives of hundreds of people in Tampa (Manna-Rea, 2020). They have earned a sense of belonging, pride, and purpose due to the bike repairing skills at the shop, the tools they have bought, and the freedom to move about the city for job opportunities. The program, which started with no money, had an innovative leader, Dengler, who thought about the source of labor and how to collect the thousands of bikes abandoned in the city. The organization has a website to market and sell its bicycles, parts, and merchandise. Dengler supports the social entrepreneurial spirit indicating that it is better to donate to such organizations or purchase their products instead of giving food to the homeless because, without the skills earned from the enterprises, the individual will be hungry again in a few hours and demand food (Manna-Rea, 2020).

\section{Conclusion}

This research has interpreted the principles of social entrepreneurship and the importance of intellectual capital. The paper has indicated that social enterprises are not started to make an income for people and profits for the proprietors but to use technology and innovation to impact society. Social enterprises transform a non-profit organization into a mixed-motive organization, making profits and employment and helping society. These enterprises have given innovators a reason to continue producing new ideas for solving society's needs. Intellectual capital became a topic of interest over a decade ago when the new knowledge-based economy was introduced. The knowledge 
economy shifted its attention from tangible assets to intangible assets that organizations own and manage. For organizations operating in the modern economy, intangible assets are highly prized compared to physical assets. Intellectual capital is valuable because intangible assets are more valuable to a business operating in the knowledge economy. The paper has explored the three dimensions of intellectual capital, human capital, structural capital, and relational capital. It is imperative to establish that organizations upholding the intellectual capital as their most valued asset have heightened their performance significantly. Social enterprises require innovative and creative young minds to find resolutions to the most daring encounters they face. When an organization is expected to operate with minimal resources and solve a community challenge, it needs to be innovative and creative. Social initiatives are expected to focus more on the talents of their teams, the management of the business, and the structures set in place to run it.

\section{References}

Abdullah, D. F., \& Sofian, S. (2012). The relationship between intellectual capital and corporate performance. Procedia-Social and Behavioral Sciences, 40, 537-541.

Abu-Saifan, S. (2012). Social entrepreneurship: definition and boundaries. Technology innovation management review, $2(2)$.

Agoston, S. I. (2014). Intellectual capital in social enterprises. Management $\mathcal{E}$ Marketing, 9(4), 423.

Akhavan, P., Rahimi, A. Mehralian, G. (2013). Developing a Model for Knowledge Sharing in Research Centers. VINE: The Journal of Information and Knowledge Management Systems, 43, 357-393. https://doi.org/10.1108/VINE-o6-2012-0020

Alzuod, M., Isa, M., \& Ismail, S. (2017). Intellectual capital, innovative performance and the moderating effect of entrepreneurial orientation among small and medium-sized enterprises in Jordan. International Review of Management and Marketing, 7(2), 308-314.

Anwar, M., Khan, S. Z., \& Khan, N. U. (2018). Intellectual capital, entrepreneurial strategy and new ventures performance: Mediating role of competitive advantage. Business and Economic Review, 10(1), 63-93.

Ariff, A.H., Islam, A. \& van Zijl, T. (2016). Intellectual Capital and Market Performance: The Case of Multinational R\&D Firms in the US. The Journal of Developing Areas, 50, 487-495. https://doi.org/10.1353/jda.2016.0052

Asiaei, K., Jusoh, R., \& Bontis, N. (2018). Intellectual capital and performance measurement systems in Iran. Journal of Intellectual Capital.

Asrar-ul-Haq, M. \& Anwar, S. (2016). A Systematic Review of Knowledge Management and Knowledge Sharing: Trends, Issues, and Challenges. Cognet Business and Management, 3, 1-17. https://doi.org/10.108o/23311975.2015.1127744

Baima, G., Forliano, C., Santoro, G., \& Vrontis, D. (2020). Intellectual capital and business model: a systematic literature review to explore their linkages. Journal of Intellectual Capital.

Bayraktaroglu, A. E., Calisir, F., \& Baskak, M. (2019). Intellectual capital and firm performance: an extended VAIC model. Journal of Intellectual Capital.

Benevene, P., Kong, E., De Carlo, A., Lucchesi, M., \& Cortini, M. (2018). A qualitative study on the perception of intellectual capital among a group of senior managers of Italian social enterprises. Knowledge Management Research E Practice.

Benevene, P., Kong, E., Barbieri, B., Lucchesi, M., \& Cortini, M. (2017). Representation of intellectual capital's components amongst Italian social enterprises. Journal of Intellectual Capital.

Bleoca, L. (2016). The Usefulness of Innovation and Intellectual Capital in Business Performance: The Financial Effects of Knowledge Management vs. Disclosure. Frederiksberg: Copenhagen Business School (CBS).

Bin Ahmad, S., \& Mushraf, A. M. (2011). The Relationship between Intellectual capital and Business Performance: An empirical study in Iraqi industry. In International Conference on Management and Artificial Intelligence Bali, Indonesia.

Bontis, N., Ciambotti, M., Palazzi, F., \& Sgro, F. (2018). Intellectual capital and financial performance in cooperative social enterprises. Journal of Intellectual Capital.

Carraher, S. M., Welsh, D. H., \& Svilokos, A. (2016). Validation of a measure of social entrepreneurship. European Journal of International Management, 10(4), 386-402.

Chahal, H., \& Bakshi, P. (2014). Effect of intellectual capital on competitive advantage and business performance: Role of innovation and learning culture. International Journal of Learning and Intellectual Capital, 11(1), 5270. 
Chahal, H. and Bakshi, P. (2016) Measurement of Intellectual Capital in the Indian Banking Sector. The Journal of Decision Makers, 41, 61-73. https://doi.org/10.1177/0256090916629253

Cisneros, M. A. I., \& Hernandez-Perlines, F. (2018). Intellectual capital and Organization performance in the manufacturing sector of Mexico. Management Decision.

Chu, S. K. W., Chan, K. H., Yu, K. Y., Ng, H. T., \& Wong, W. K. (2011). An empirical study of the impact of intellectual capital on business performance. Journal of Information E Knowledge Management, 10(o1), 11-21.

Cleary, P., \& Quinn, M. (2016). Intellectual capital and business performance: An exploratory study of the impact of cloud-based accounting and finance infrastructure. Journal of Intellectual Capital.

Cukier, W., Trenholm, S., Carl, D., \& Gekas, G. (2011). Social entrepreneurship: A content analysis. Journal of Strategic Innovation and Sustainability, 7(1), 99-119.

Dacin, M. T., Dacin, P. A., \& Tracey, P. (2011). Social entrepreneurship: A critique and future directions. Organization Science, 22(5), 1203-1213.

El Ebrashi, R. (2013). Social entrepreneurship theory and sustainable social impact. Social Responsibility Journal.

Eniola, A. A., Entebang, H., \& Sakariyau, O. B. (2015). Small and medium scale business performance in Nigeria: Challenges faced from an intellectual capital perspective. International Journal of Research Studies in Management, 4(1), 59-71.

Franz, H. W., Hochgerner, J., \& Howaldt, J. (Eds.). (2012). Challenge social innovation: potentials for business, social entrepreneurship, welfare, and civil society. Springer Science \& Business Media.

Ginesti, G., Caldarelli, A., \& Zampella, A. (2018). Exploring the impact of intellectual capital on company reputation and performance. Journal of Intellectual Capital.

Groot, A., \& Dankbaar, B. (2014). Does social innovation require social entrepreneurship?. Technology Innovation Management Review, 4(12).

Hajir, J.A., Obeidat, B.Y., Al-dalahmeh, M.A. and Masa'deh, R. (2015) The Role of Knowledge Management Infrastructure in Enhancing Innovation at Mobile Telecommunication Companies in Jordan. European Journal of Social Sciences, 50, 313-330.

Hamdan, A. (2018). Intellectual capital and firm performance. International Journal of Islamic and Middle Eastern Finance and Management.

Hechavarría, D. M., \& Welter, C. (2015). Opportunity types, social entrepreneurship, and innovation: Evidence from the panel study of entrepreneurial dynamics. The International Journal of Entrepreneurship and Innovation, 16(4), 237-251.

Hussinki, H., Ritala, P., Vanhala, M., \& Kianto, A. (2017). Intellectual capital, knowledge management practices, and firm performance. Journal of Intellectual Capital.

Huybrechts, B., \& Nicholls, A. (2012). Social entrepreneurship: Definitions, drivers, and challenges. In Social entrepreneurship and social business (pp. 31-48). Gabler Verlag.

Inkinen, H. (2015). Review of empirical research on intellectual capital and firm performance. Journal of Intellectual capital.

Jain, P., Vyas, V., \& Roy, A. (2017). Exploring the mediating role of intellectual capital and competitive advantage on the relation between CSR and financial performance in SMEs. Social Responsibility Journal.

Joshi, M., Cahill, D., Sidhu, J. \& Kansal, M. (2013). Intellectual Capital and Financial Performance: An Evaluation of the Australian Financial Sector. Journal of Intellectual Capita, 14, $264-285$. https://doi.org/10.1108/14691931311323887

Kalkan, A., Bozkurt, Ö. Ç., \& Arman, M. (2014). The impacts of intellectual capital, innovation, and organizational strategy on firm performance. Procedia-social and behavioral sciences, 150, 700-707.

Kamukama, N. (2013) Intellectual Capital: Company's Invisible Source of Competitive Advantage. Competitiveness Review: An International Business Journal, 23, 26o-283. https://doi.org/10.1108/10595421311319834

Kamukama, N., Ahiauzu, A., \& Ntayi, J. M. (2010). Intellectual capital and performance: testing interaction effects. Journal of intellectual capital.

Kamukama, N., Ahiauzu, A., \& Ntayi, J. M. (2011). Competitive advantage: mediator of intellectual capital and performance. Journal of intellectual capital.

Kateb, G.A., Swies, R., Masa'deh, R. \& Maqableh, M. (2014). An Investigation on the Critical Factors of Information System Implementation in Jordanian Information Technology Companies. European Journal of Business and Management, 7, 11-28.

Käpylä, J., Kujansivu, P., \& Lönnqvist, A. (2012). National intellectual capital performance: a strategic approach. Journal of Intellectual Capital.

Karchegani, M. R., Sofian, S., \& Amin, S. M. (2013). The relationship between intellectual capital and innovation: a review. International journal of business and management studies, 2(1), 561-581. 
Komnenic, B., \& Pokrajčić, D. (2012). Intellectual capital and corporate performance of MNCs in Serbia. Journal of Intellectual Capital.

Kong, E. (2010). Innovation processes in social enterprises: an IC perspective. Journal of Intellectual Capital.

Khalique, M., Bontis, N., Shaari, J. A. N. B., Yaacob, M. R., \& Ngah, R. (2018). Intellectual capital and organizational performance in Malaysian knowledge-intensive SMEs. International Journal of Learning and Intellectual Capital, 15(1), 20-36.

Khan, S. N., \& Ali, E. I. E. (2017). The moderating role of intellectual capital between enterprise risk management and firm performance: A conceptual review. American Journal of Social Sciences and Humanities, 2(1), 9-15.

Kim, T., Kim, W. G., Park, S. S. S., Lee, G., \& Jee, B. (2012). Intellectual capital and business performance: What structural relationships do they have in upper-upscale hotels?. International Journal of Tourism Research, 14(4), 391-408.

Kuo, T. (2011) How to Improve Organizational Performance through Learning and Knowledge? International Journal of Manpower, 32, 581-603. https://doi.org/10.1108/01437721111158215

Lai, W. (2013) Interoperability of Implicit and Explicit Firm-Level Knowledge Accumulation. Journal of Strategy and Management, 6, 229-241. https://doi.org/10.1108/JSMA-08-2012-0042

Lepoutre, J., Justo, R., Terjesen, S., \& Bosma, N. (2013). Designing a global standardized methodology for measuring social entrepreneurship activity: the Global Entrepreneurship Monitor social entrepreneurship study. Small Business Economics, 40(3), 693-714.

Liu, C. H. (2017). The relationships among intellectual capital, social capital, and the performance-The moderating role of business ties and environmental uncertainty. Tourism Management, 61, 553-561.

Maditinos, D., Chatzoudes, D., Tsairidis, C., \& Theriou, G. (2011). The impact of intellectual capital on firms' market value and financial performance. Journal of intellectual capital.

Madyan, M., \& Fikir, H. R. (2019). Intellectual Capital, Financial Performance, and Value of Company. Journal of Advanced Research in Dynamical and Control System, 11, 1276-1284.

Manna-Rea, J. C. (2020, February 20). Hope after tragedy: John Dengler's impact on homelessness. The Oracle. https://www.usforacle.com/2020/o2/20/hope-after-tragedy-john-denglers-impact-on-homelessness/

Martin, R. L., \& Osberg, S. (2015). Getting beyond better: How social entrepreneurship works. Harvard Business Review Press.

Masa'deh, R., Obeidat, B. and Tarhini, A. (2016) A Jordanian Empirical Study of the Associations among Transformational Leadership, Transactional Leadership, Knowledge Sharing, Job Performance, and Firm Performance: A Structural Equation Modelling Approach. Journal of Management Development, 35, 681705. https://doi.org/10.1108/JMD-09-2015-0134

Massaro, M., Dal Mas, F., Bontis, N., \& Gerrard, B. (2019). Intellectual capital and performance in temporary teams. Management Decision.

Matos, F., \& Vairinhos, V. M. (2017). Intellectual capital management as a driver of competitiveness and sustainability. Journal of Intellectual Capital.

Mehralian, G., Rajabzadeh, A., Sadeh, M. R., \& Rasekh, H. R. (2012). Intellectual capital and corporate performance in the Iranian pharmaceutical industry. Journal of intellectual capital.

Mention, A. L., \& Bontis, N. (2013). Intellectual capital and performance within the banking sector of Luxembourg and Belgium. Journal of Intellectual capital.

Mondal, A., \& Ghosh, S. K. (2012). Intellectual capital and financial performance of Indian banks. Journal of Intellectual Capital. https://doi.org/10.1108/14691931211276115

Mthembu, A., \& Barnard, B. (2019). Social Entrepreneurship: Objectives, innovation, implementation, and impact on entrepreneurship. Innovation, Implementation, and Impact on Entrepreneurship (February 27, 2019).

Mushref, A. M. (2014). The moderator role of organizational culture between intellectual capital and business performance: An empirical study in Iraqi industry. Net Journal of Social Sciences, 2(3), 82-91.

Noradiva, H., Parastou, A., \& Azlina, A. (2016). The Effects of Managerial Ownership on the Relationship between Intellectual Capital Performance and Firm Value. International Journal of Social Science and Humanity, 6(7), 514-518. https://doi.org/10.7763/ijssh.2016.v6.702

Obeidat, B. Y., Al-Suradi, M. M., \& Tarhini, A. (2016). The impact of knowledge management on innovation: An empirical study on Jordanian consultancy firms. Management Research Review.

Örnek, A. S.., \& Ayas, S. (2015). The relationship between intellectual capital, innovative work behavior, and business performance reflection. Procedia-Social and Behavioral Sciences, 195, 1387-1395.

Pedro, E., Leitão, J., \& Alves, H. (2018). Intellectual capital and performance. Journal of Intellectual Capital.

Phillips, W., Lee, H., Ghobadian, A., O'Regan, N., \& James, P. (2015). Social innovation and social entrepreneurship: A systematic review. Group \& Organization Management, 4o(3), 428-461. 
Phusavat, K., Comepa, N., Sitko-Lutek, A., \& Ooi, K. B. (2011). Interrelationships between intellectual capital and performance. Industrial Management \& Data Systems.

Praszkier, R., \& Nowak, A. (2011). Social entrepreneurship: Theory and practice. Cambridge University Press.

Rahim, H. L., \& Mohtar, S. (2015). Social entrepreneurship: A different perspective. International Academic Research Journal of Business and Technology, 1(1), 9-15.

Saebi, T., Foss, N. J., \& Linder, S. (2019). Social entrepreneurship research: Past achievements and future promises. Journal of Management, 45(1), 70-95.

Salvi, A., Vitolla, F., Giakoumelou, A., Raimo, N., \& Rubino, M. (2020). Intellectual capital disclosure in integrated reports: The effect on firm value. Technological Forecasting and Social Change, 160, 120228.

Santos, F. M. (2012). A positive theory of social entrepreneurship. Journal of business ethics, 111(3), 335-351.

Sardo, F., Serrasqueiro, Z., \& Alves, H. (2018). On the relationship between intellectual capital and financial performance: A panel data analysis on SME hotels. International Journal of Hospitality Management, 75, 6774.

Sarwenda, B. (2020). Intellectual capital, business performance, and competitive advantage: An empirical study for the pharmaceutical companies. Quality Access to Success, 103-106.

Scafarto, V., Ricci, F., \& Scafarto, F. (2016). Intellectual capital and firm performance in the global agribusiness industry. Journal of Intellectual Capital.

Sharabati, A. A. A., Nour, A. N. I., \& Shamari, N. S. (2013). The impact of intellectual capital on Jordanian telecommunication companies' business performance. American Academic \& Scholarly Research Journal, 5 (3 special issues), 32 .

Shehzad, U., Fareed, Z., Zulfiqar, B., Shahzad, F., \& Latif, H. S. (2014). The impact of intellectual capital on the performance of universities. European Journal of Contemporary Education, 10(4), 273-28o.

Sherif, M. and Elsayed, M. (2016) The Impact of Intellectual Capital on Corporate Performance: Evidence from the Egyptian Insurance Market. International Journal of Innovation Management, $20,1-47$. https://doi.org/10.1142/S1363919616500341

Smriti, N., \& Das, N. (2017). Impact of intellectual capital on business performance: evidence from Indian pharmaceutical sector. Polish Journal of Management Studies, 15.

Susanti, N., Widajatun, V. W., Aji, M. B., \& Nugraha, N. M. (2020). Implications of intellectual capital financial performance and corporate values. International Journal of Psychosocial Rehabilitation, 24(o7).

Sgrò, F., Ciambotti, G., Bontis, N., \& Ayiku, A. (2020). Intellectual capital in East and West African social enterprises. Knowledge and Process Management, 27(4), 332-344.

Shah, N., \& Shah, S. G. S. (2010). Relationships between employee readiness for organizational change, supervisor and peer relations, and demography. Journal of Enterprise Information Management. https://doi.org/10.1108/17410391011083074

Shannak, R., Obeidat, B., \& Almajali, D. (2010, June). Information technology investments: A literature review. In Proceedings of the 14th IBIMA conference on global business transformation through innovation and knowledge management: An academic perspective, Istanbul-Turkey, 23rd-24th June (pp. 1356-1368).

Shou, Y., Prester, J., \& Li, Y. (2018). The impact of intellectual capital on supply chain collaboration and business performance. IEEE Transactions on Engineering Management, 67(1), 92-104.

The, P. and Sun, H. (2012) Knowledge Sharing, Job Attitudes, and Organisational Citizenship Behaviour. Industrial Management \& Data Systems, 112, 64-82. https://doi.org/10.1108/02635571211193644

Todericiu, R., \& Șerban, A. (2015). The Assessment of Intellectual Capital in Romanian Universities. Studies in Business and Economics, 10(3), 100-110.

Torre, C., Tommasetti, A., \& Maione, G. (2020). Technology usage, intellectual capital, firm performance and employee satisfaction: the accountants' idea. The TQM Journal.

Toth, Z. and Jonas, T. (2012) Measuring Intellectual Capital in the Light of the EFQM Excellence Model: Evidence from Hungary. International Journal of Quality and Service Sciences, 4, 316-331. https://doi.org/10.1108/17566691211288313

Uwuigbe, U., \& Uadiale, O. M. (2011). Intellectual capital and business performance: evidence from Nigeria. Interdisciplinary Journal of Research in Business, 1, 49-56.

Vratskikh, I., Masa'deh, R., Al-Lozi, M. \& Maqableh, M. (2016). The Impact of Emotional Intelligence on Job Performance via the Mediating Role of Job Satisfaction. International Journal of Business and Management, 11, 69-91. https://doi.org/10.5539/ijbm.v11n2p69

Wendling, M., Oliveira, M. \& Macada, A. (2013). Knowledge Sharing Barriers in Global Teams. Journal of Systems and Information Technology, 15, 239-253. https://doi.org/10.1108/JSIT-09-2012-0054

Whelan, E. and Carcary, M. (2011) Integrating Talent and Knowledge Management: Where are the Benefits? Journal of Knowledge Management, 15, 675-687. https://doi.org/10.1108/13673271111152018 
Xu, J., \& Wang, B. (2018). Intellectual capital, financial performance and companies' sustainable growth: Evidence from the Korean manufacturing industry. Sustainability, 10(12), 4651.

Xu, X. L., Yang, X. N., Zhan, L., Liu, C. K., Zhou, N. D., \& Hu, M. (2017). Examining the relationship between intellectual capital and performance of listed environmental protection companies. Environmental Progress \& Sustainable Energy, 36(4), 1056-1066.

$\mathrm{Xu}, \mathrm{J} .$, \& Li, J. (2019). The impact of intellectual capital on SMEs' performance in China: Empirical evidence from non-high-tech vs. high-tech SMEs. Journal of Intellectual Capital.

Yusoff, Y. M., Omar, M. K., Zaman, M. D. K., \& Samad, S. (2019). Do all elements of green intellectual capital contribute toward business sustainability? Evidence from the Malaysian context using the Partial Least Squares method. Journal of Cleaner Production, 234, 626-637.

Zeglat, D., \& Zigan, K. (2013). Intellectual capital and its impact on business performance: Evidence from the Jordanian hotel industry. Tourism and Hospitality Research, 13(2), 83-100. 